\title{
Pemanfaatan Tandan Kosong Kelapa Sawit sebagai Bahan Baku Kertas Karbon
}

\author{
Fredina Destyorini* dan Nanik Indayaningsih \\ Pusat Penelitian Fisika - LIPI, Gd. 440 Kawasan PUSPIPTEK, Tangerang Selatan, Indonesia \\ E-mail: *fred007@lipi.go.id
}

Masuk: 9 Agustus 2017

Direvisi : 30 Agustus 2017 Disetujui : 11 Agustus 2017

\begin{abstract}
Abstrak: Limbah perkebunan berupa tandan kosong kelapa sawit (TKKS) dapat dimanfaatkan sebagai bahan karbon yang bernilai guna lebih tinggi. Pada penelitian ini dibahas tentang proses pembuatan dan karakterisasi kertas karbon dengan memanfaatkan serat TKKS sebagai bahan bakunya. Kertas karbon yang dihasilkan dapat diaplikasikan sebagai Gas Diffusion Layer (GDL) PEMFC. Pembuatan kertas karbon pada penelitian kali ini terdiri dari 2 tahap yaitu pembuatan bahan karbon dari serat TKKS dan pembuatan kertas karbon. Pada tahap pertama, bahan karbon dihasilkan dari proses karbonisasi dan pirolisis serat TKKS hingga suhu $1300^{\circ} \mathrm{C}$. Bahan karbon yang dihasilkan selanjutnya digunakan sebagai bahan dasar untuk pembuatan kertas karbon pada tahap kedua. Pembuatan kertas karbon dilakukan dengan cara mencampurkan bahan karbon yang dihasilkan pada tahap pertama dengan polimer ethylene vinyl acetate (EVA) dan poly ethylene glycol (PEG) sebagai binder ke dalam pelarut xylene. Proses pencampuran dilakukan pada suhu $90^{\circ} \mathrm{C}$ hingga membentuk slurry, dan dilanjutkan dengan proses pencetakan pada cetakan kaca. Berdasarkan hasil pengujian konduktivitas listrik terlihat bahwa nilai konduktivitas listrik karbon TKKS meningkat seiring dengan pertambahan suhu pirolisis. Nilai konduktivitas listrik serbuk karbon TKKS $500^{\circ} \mathrm{C}$ sebesar $\left(1,02 \times 10^{-6}\right)-\left(3,90 \times 10^{-5}\right) \mathrm{S} / \mathrm{cm} ; 700^{\circ} \mathrm{C}$ sebesar $(0,021-0,025) \mathrm{S} / \mathrm{cm} ; 900^{\circ} \mathrm{C}$ sebesar $(2,95-$ $2,96) \mathrm{S} / \mathrm{cm}$; dan untuk $1300^{\circ} \mathrm{C}$ sebesar $(7,97-8,03) \mathrm{S} / \mathrm{cm}$. Penggunaan bahan polimer yang tidak konduktif menyebabkan kertas karbon yang dihasilkan memiliki nilai konduktivtas listrik yang lebih rendah dibandingkan bahan karbonnya.
\end{abstract}

Kata kunci: Tandan kosong kelapa sawit, pirolisis, kertas karbon, Gas Diffusion Layer

\begin{abstract}
Farm by-products such as oil palm empty fruit bunches $(E F B)$ can be used as the carbon material with higher usevalue. In this study discussed about the manufacture process and characterization of carbon paper using EFB as raw materials. The carbon paper can be applied as a Gas Diffusion Layer (GDL) PEMFC. Manufacture of carbon paper in the present study consisted of two stages, namely the manufacture of carbon materials and paper making. In the first stage, the carbon material produced from carbonization and pyrolysis process of EFB to a suhu of $1300^{\circ} \mathrm{C}$. The resulting carbon material is further used as a raw material for the manufacture of carbon paper on the second stage. Manufacture of carbon paper made by mixing the carbon material produced in the first stage with a polymer of ethylene vinyl acetate (EVA) and poly ethylene glycol (PEG) as binder in the solvent xylene. The mixing process is done at a suhu of $90^{\circ} \mathrm{C}$ to form slurry, and then cast it on the glass mold. Based on the result of electrical conductivity test shows that the electrical conductivity of carbon material from TKKS increases with pyrolysis suhu. The electrical conductivity value of carbon TKKS $500^{\circ} \mathrm{C}$ are $\left(1,02 \times 10^{-6}\right)-\left(3,90 \times 10^{-5}\right) \mathrm{S} / \mathrm{cm} ; 700^{\circ} \mathrm{C}(0,021-0,025) \mathrm{S} / \mathrm{cm} ; 900^{\circ} \mathrm{C}(2,95$ to 2,96$) \mathrm{S} / \mathrm{cm}$; and $1300^{\circ} \mathrm{C}(7,97$ to 8.03$) \mathrm{S} / \mathrm{cm}$. The use of non-conductive polymer materials in the second stage produced carbon paper with lower electrical conductivity than the carbon materials.
\end{abstract}

Keywords: Oil palm empty fruit bunches, pyrolysis, carbon paper, Gas Diffusion Layer

\section{PENDAHULUAN}

Indonesia merupakan salah satu penyuplai minyak kelapa sawit mentah (Crude Palm Oil/ CPO) terbesar di dunia [1]. Pada tahun 2011 Indonesia menguasai pasar CPO (crude palm oil) atau minyak mentah sawit dunia sebesar $47 \%$, Malaysia sebesar $39 \%$ dan selebihnya di produksi oleh negara lain di seluruh dunia. Dari total seluruh produksi CPO tahun 2011 dengan jumlah 46 juta ton yang di hasilkan dari lebih kurang 12 juta hektar kelapa sawit di seluruh dunia, Indonesia berkontribusi sebanyak 7,5 juta hektar [2-4]. Dalam proses pengolahan 
minyak kelapa sawit terdapat produk samping (limbah) salah satunya berupa tandan kosong kelapa sawit (TKKS) yang selama ini belum dimanfaatkan secara optimal, contohnya sebagai pupuk tanaman dan pakan ternak saja. Sedangkan TKKS merupakan limbah padat yang paling banyak dihasilkan yaitu $>20 \%$ dari total tandan buah segar (TBS) kelapa sawit yang diolah [5]. Pada penelitian ini akan dilakukan pengolahan tandan kosong kelapa sawit menjadi arang aktif dan kertas karbon sebagai alternatif pemanfaatan limbah kelapa sawit yang sudah ada selama ini. TKKS merupakan bahan organik komplek yang kaya unsur karbon. Kandungan karbon inilah yang dapat dimanfaatkan untuk berbagai aplikasi, salah satunya sebagai arang/karbon aktif dan kertas karbon konduktif. Tujuan dari penelitian kali ini yaitu untuk mempelajari teknik pengolahan TKKS menjadi arang/karbon aktif dan pembuatan kertas karbon konduktif dari arang/karbon aktif TKKS pada variasi temperatur pemanasan. Hasil penelitian ini diharapkan dapat meningkatkan nilai tambah limbah TKKS dibanding dengan aplikasi yang sudah ada selama ini.

\section{METODOLOGI}

\section{Bahan Baku}

Bahan baku yang digunakan dalam penelitian ini yaitu serat dari tandan kosong kelapa sawit (TKKS). Pembuatan kertas karbon diawali dengan proses karbonisasi serat dari TKKS pada suhu $500^{\circ} \mathrm{C}$ dalam kondisi inert gas $\left(\mathrm{N}_{2}\right)$ selama 1 jam untuk menghasilkan arang $500^{\circ} \mathrm{C}$ menggunakan tungku tabung. Berdasarkan hasil DTA/TG, serat TKKS telah mengalami dekomposisi seluruh komponen hemi-cellulose, cellulose and lignin pada suhu $\pm 500^{\circ} \mathrm{C}$ [3]. Pembuatan arang/karbon aktif $700^{\circ} \mathrm{C}, 900^{\circ} \mathrm{C}$, dan $1300^{\circ} \mathrm{C}$ dilakukan dengan melanjutkan proses pemanasan pada suhu $700^{\circ} \mathrm{C}, 900^{\circ} \mathrm{C}$, dan $1300^{\circ} \mathrm{C}$ dalam kondisi inert gas $\left(\mathrm{N}_{2}\right)$ selama 1 jam dari arang $500^{\circ} \mathrm{C}$.

\section{Pembuatan Kertas Karbon Konduktif}

Kertas karbon konduktif (CCP) dibuat menggunakan teknologi komposit, dengan bahan serbuk arang/karbon TKKS (200 mesh), polimer dan pelarut. Polimer yang digunakan yaitu jenis Ethylene vinyl acetate (EVA) dan Polyethylene glycol (PEG), sedangkan pelarut yang digunakan yaitu jenis Xylen. Detil proses pembuatan kertas kabon konduktif dapat dilihat pada diagram alir (Gambar 1).

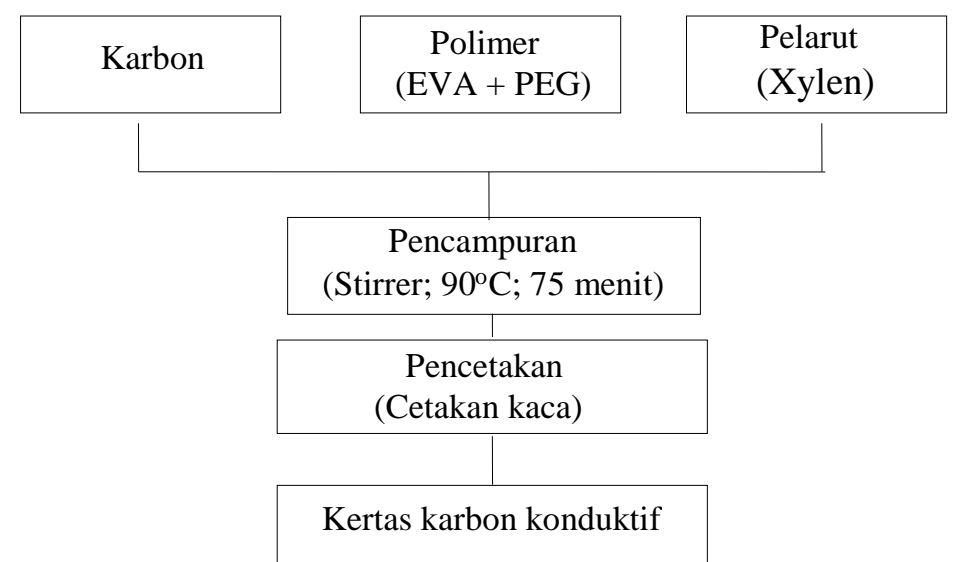

Gambar 1. Diagam alir pembuatan kertas karbon.

\section{Karakterisasi}

Nilai konduktivitas listrik serbuk arang/karbon TKKS dan kertas karbon diukur menggunakan LCR-meter HIOKI 3522-50 HITESTER. Untuk serbuk arang/karbon ukuran partikel dibuat homogen sebesar 200 mesh. Sedangkan sampel kertas karbon dipotong seluas $\pm(1 \mathrm{x} 1) \mathrm{cm}^{2}$. Dari alat LCR-meter ini didapatkan nilai resistansi (R) dengan satuan $\Omega$, dan untuk mendapatkan nilai konduktivitas listriknya $(\sigma) \mathrm{S} / \mathrm{cm}$ digunakan persamaan (1):

$$
\sigma=\frac{R A}{L}
$$

dimana $\mathrm{L}$ adalah jarak 2 elektroda dengan satuan $\mathrm{cm}$, dan $\mathrm{A}$ adalah luas penampang lintang dengan satuan $\mathrm{cm}^{2}$ [6]. Pengamatan morfologi kertas karbon konduktif dilakukan menggunakan SEM (JEOL JSM-6390A). Pengamatan dilakukan pada penampang atas, bawah, dan melintang dari kertas karbon. 


\section{HASIL DAN PEMBAHASAN}

Tandan kosong kelapa sawit merupakan serat organik yang kaya akan unsur karbon. Unsur kabon yang terikat dalam bentuk hemi-cellulose, cellulose and lignin inilah yang harus diuraikan dengan teknik karbonisasi pada suhu tertentu. Pada penelitian ini unsur karbon yang terkandung dalam serat TKKS dimanfaatkan sebagai bahan baku pembuatan kertas karbon konduktif. Proses pengarangan serat karbon untuk mendapat unsur karbon yang diinginkan dilakukan dengan teknik karbonisasi (inert gas) dimulai pada suhu $500^{\circ} \mathrm{C}$ selama 1 jam. Serat TKKS yang telah melalui proses karbonisasi akan berubah warna menjadi hitam pekat seperti warna arang. Bentuk serat TKKS sebelum dikarbonisasi dan arang TKKS setelah karbonisasi dapat dilihat pada Gambar 2a dan 2b. Dengan mengalirkan gas inert $\left(\mathrm{N}_{2}\right)$ selama proses karbonisasi akan menyebabkan serat TKKS terdekomposisi sempurna dan mencegah terbentuknya abu sebagai akibat dari reaksi dengan oksigen. Indikasi tidak terbentuknya abu dapat ditandai dengan warna arang yang hitam pekat dan tidak ada bagian yang berwarna abu-abu atau putih. Proses karbonisasi pada suhu $500^{\circ} \mathrm{C}$ ini menghasilkan produk samping berupa tar dan cuka kayu yang harus dipisahkan dari arang/karbon. Selanjutnya arang $500^{\circ} \mathrm{C}$ ini dipanaskan lagi pada suhu yang lebih tinggi yaitu $700^{\circ} \mathrm{C}, 900^{\circ} \mathrm{C}, 1300^{\circ} \mathrm{C}$ dengan tujuan meningkatkan kualitasnya.

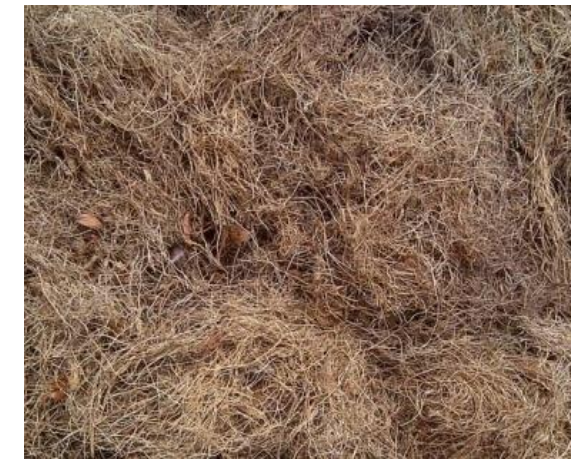

(a)

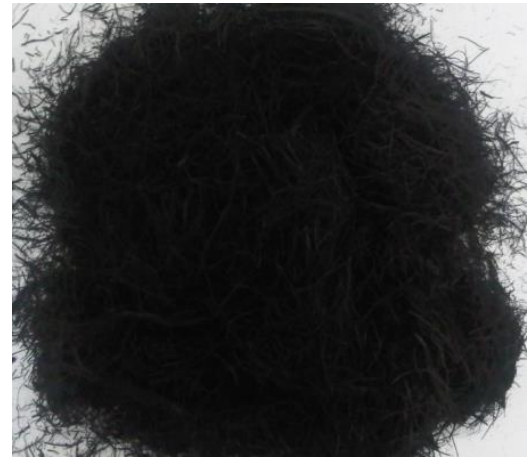

(b)

Gambar 2. Foto TKKS (a) sebelum dikarbonisasi dan (b) arang setelah dikarbonisasi.

Sebagai bahan baku untuk membuat kertas karbon konduktif, arang/karbon dari serat TKKS harus memiliki konduktivitas listrik yang tinggi. Oleh karena itu perlu adanya pengukuran nilai konduktivitas arang/karbon dari serat TKKS hasil karbonisasi pada suhu 500, 700, 900, dan $1300^{\circ} \mathrm{C}$. Arang/karbon dari serat TKKS ini harus diserbukkan terlebih dahulu dengan ukuran serbuk homogen 200 mesh untuk memaksimalkan kontak antar partikelnya selama proses pengukuran. Hasil pengukuran nilai konduktivitas listrik arang/karbon TKKS disajikan pada Gambar 3.

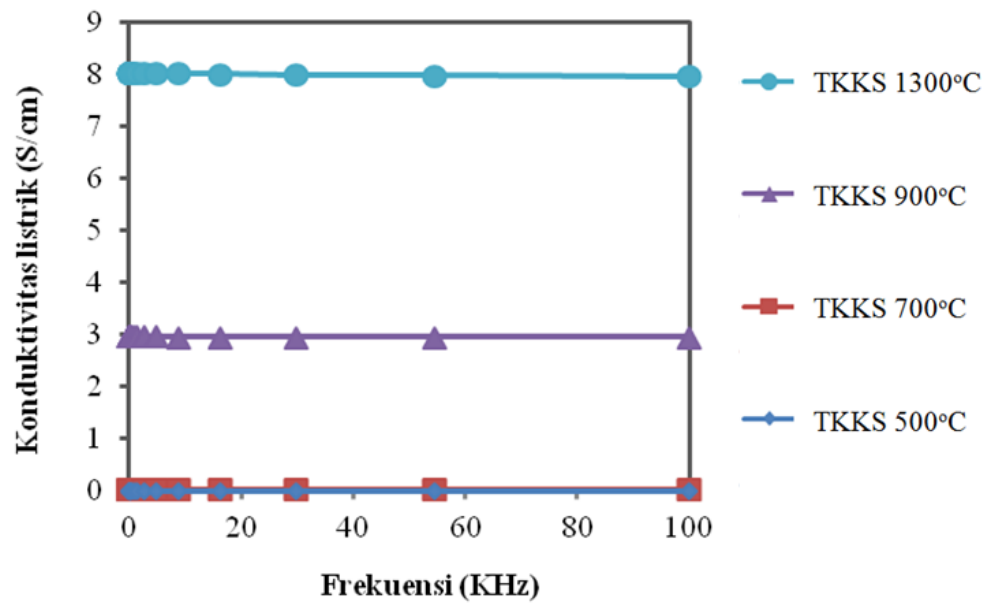

Gambar 3. Konduktivitas listrik serbuk arang/karbon TKKS dengan variasi suhu pemanasan. 
10 | Fredina Destyorini, dkk., Pemanfaatan Tandan Kosong Kelapa Sawit....,

Dari Gambar 3 terlihat bahwa nilai konduktivitas listrik arang/karbon TKKS meningkat seiring dengan pertambahan suhu proses karbonisasi. Nilai konduktivitas listrik arang/karbon TKKS $500^{\circ} \mathrm{C}$ sebesar $\left(1,02 \times 10^{-6}\right)$ $\left(3,90 \times 10^{-5}\right) \mathrm{S} / \mathrm{cm} ; 700^{\circ} \mathrm{C}$ sebesar $(0,021-0,025) \mathrm{S} / \mathrm{cm} ; 900^{\circ} \mathrm{C}$ sebesar $(2,95-2,96) \mathrm{S} / \mathrm{cm}$; dan untuk $1300^{\circ} \mathrm{C}$ sebesar $(7,97-8,03) \mathrm{S} / \mathrm{cm}$. Peningkatan suhu karbonisasi berpengaruh terhadap pertambahan nilai konduktivitas listrik arang/karbon TKKS. Berdasarkan hasil penelitian sebelumnya menyebutkan bahwa pertambahan suhu karbonisasi pada serat TKKS menyebabkan meningkatnya derajat kristalinitas dari arang/karbon TKKS [7-8]. Derajat kristalinitas merupakan tingkat keteraturan struktur suatu material [9]. Penetapan derajat kristalinitas dapat dilakukan dengan cara membagi luas daerah kristalin dan luas daerah seluruhnya (kristalin+amorf) [10]. Peningkatan derajat kristalinitas pada arang $500^{\circ} \mathrm{C}, 700^{\circ} \mathrm{C}, 900^{\circ} \mathrm{C}$, dan $1300^{\circ} \mathrm{C}$ memperlihatkan bahwa struktur kristal karbon pada arang semakin teratur mendekati struktur grafit dan hal ini juga mempengaruhi konduktivitas listriknya [11].

Hasil pembuatan kertas karbon konduktif dari arang/karbon TKKS dapat dilihat di Gambar 4. Kertas karbon dibuat dari arang/karbon TKKS dan polimer yang dicetak dengan teknik tape casting. Komposisi yang digunakan antara arang/karbon : polimer adalah 8:2 dengan berat total campuran sebesar 1,5 gram. Dimensi kertas yang dihasilkan sebesar $\pm(10 x 10) \mathrm{cm}$ dan tebal $\pm(0,1-0,2) \mathrm{mm}$. Pembuatan kertas karbon ini dilakukan menggunakan bahan dasar arang/karbon TKKS hasil karbonisasi suhu 500, 700, 900, dan $1300^{\circ} \mathrm{C}$ dengan komposisi yang sama. Pengukuran konduktivitas listrik pada kertas karbon juga dilakukan dan hasilnya dapat dilihat pada Gambar 5.
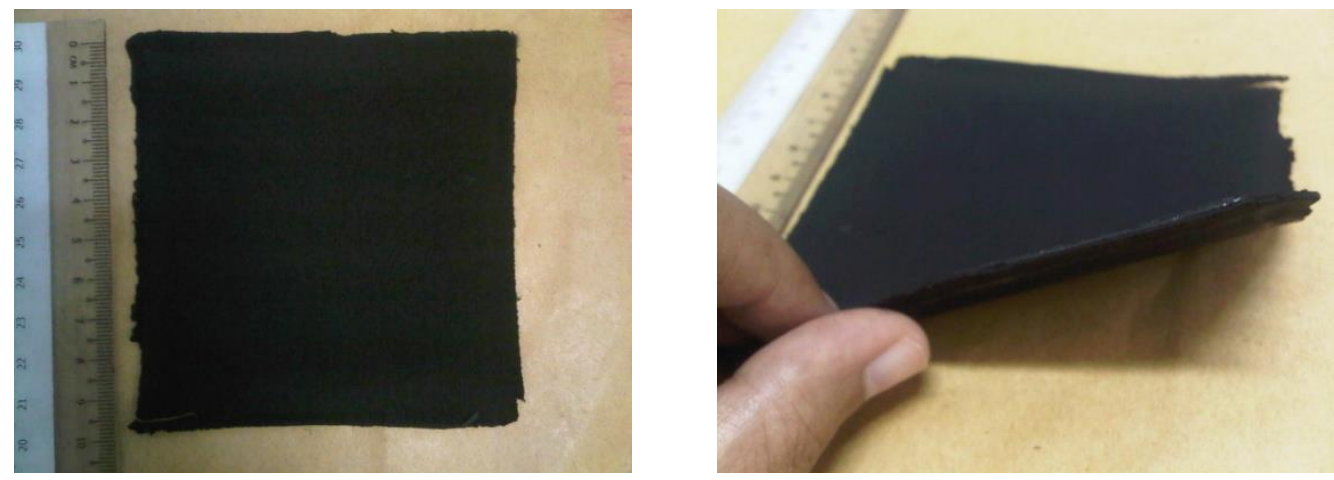

Gambar 4. Kertas karbon dari arang TKKS.

Pada Gambar 5 terlihat bahwa konduktivitas listrik kertas karbon meningkat sesuai dengan suhu karbonisasi serbuk arang/karbon TKKS yang digunakan. Kertas karbon yang menggunakan bahan dasar arang/karbon TKKS bersuhu $500^{\circ} \mathrm{C}$ memiliki konduktivitas listrik paling rendah yaitu sebesar $\left(1,37 \times 10^{-9}\right)-\left(1,44 \times 10^{-6}\right) \mathrm{S} / \mathrm{cm}$. Nilai konduktivitas listrik ini semakin naik nilainya pada kertas karbon yang menggunakan arang/karbon dengan suhu karbonisasi lebih tinggi pada 700,900 , dan $1300^{\circ} \mathrm{C}$ yaitu berturut-turut sebesar; $(3,68-3,81) \times 10^{-4} \mathrm{~S} / \mathrm{cm}$; $(5,77-5,98) \times 10^{-2} \mathrm{~S} / \mathrm{cm}$; dan $(2,34-2,40) \times 10^{-1} \mathrm{~S} / \mathrm{cm}$. Dan kertas karbon yang paling konduktif dihasilkan dari arang/karbon TKKS bersuhu $1300^{\circ} \mathrm{C}$. Nilai konduktivitas listrik kertas karbon jika dibandingkan dengan nilai konduktivitas listrik bahan dasarnya berupa serbuk arang/karbon TKKS secara keseluruhan terlihat mengalami penurunan nilai. Hal ini disebabkan adanya penambahan polimer non-konduktif sebagai binder yang dapat mengurangi kontak antar partikel karbon sehingga nilai konduktivitasnya menurun.

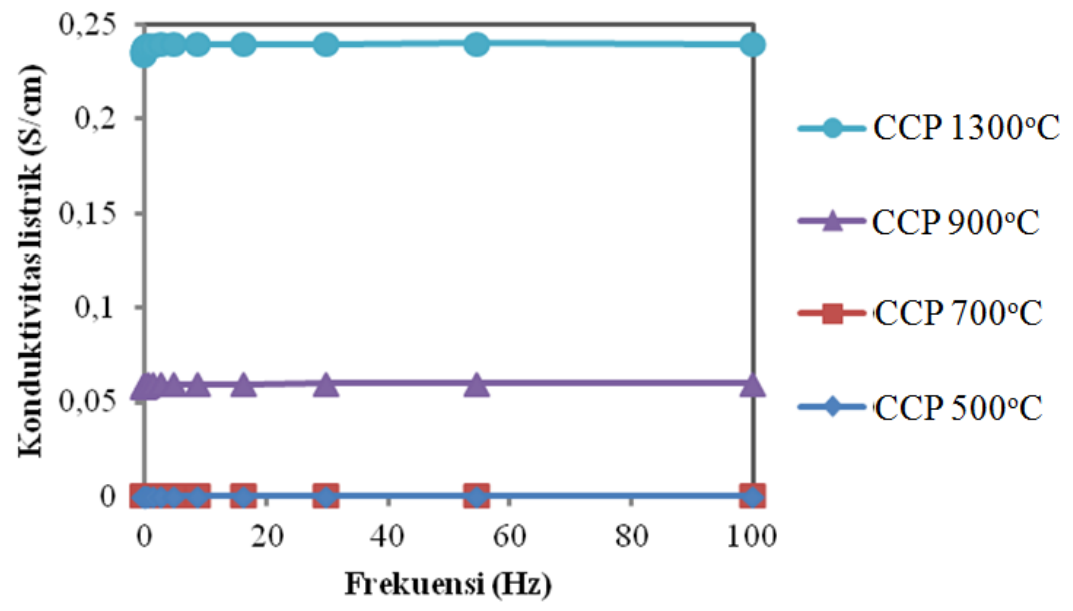

Gambar 5. Konduktivitas listrik kertas karbon dari TKKS dengan variasi suhu pemanasan serbuk karbon. 
Pengamatan menggunakan SEM juga dilakukan untuk melihat stuktur mikro pada kertas karbon. Pengamatan dilakukan pada permukaan bagian atas, permukaan bawah dan penampang lintangnya. Hasil foto SEM kertas karbon masing-masing bagian dapat dilihat pada Gambar 6. Dari hasil foto SEM pada pemukaan bagian atas dan bawah (Gambar 6a dan 6b) terlihat bahwa partikel karbon saling terikat satu sama lainnya tetapi masih terbentuk pori yang tersebar merata di seluruh permukaan. Terbentuknya pori merupakan salah satu syarat yang dibutuhkan oleh sebuah komponen elektoda PEMFC Gas Diffusion Layer yang memiliki salah satu fungsi sebagai pendistribusi gas $\mathrm{H}$ dan O [12]. Sedangkan keterikatan antar partikel karbon mempengaruhi sifat listrik dari kertas karbon yang dihasilkan. Partikel karbon yang saling terikat satu sama lain menyediakan jalur bagi elektron untuk bergerak, dan hal ini berpengaruh tehadap nilai konduktivitas listriknya. Pengamatan pada penampang lintang kertas karbon (Gambar 6c) memberikan informasi bahwa tebal kertas yang dihasilkan \pm $194,47 \mu \mathrm{m}$. Keterikatan antar patikel karbon dan pori yang terbentuk juga terlihat jelas. Dari penelitian ini dapat disimpulkan bahwa karbon dari arang TKKS dapat dimanfaatkan untuk membuat kertas karbon konduktif dengan teknologi komposit. Pemanfaatan serat tandan kosong kelapa sawit menjadi kertas karbon konduktif ini dapat menambah nilai manfaat dari limbah industri sawit yang melimpah jumlahnya. Seperti kita tahu bahwa Indonesia merupakan negara penghasil sawit terbanyak di dunia, tetapi limbah TKKS yang dihasilkan masih belum termanfaatkan secara optimal. Dengan demikian hasil penelitian ini dapat memberikan informasi mengenai alternatif pemanfaatan limbah sawit TKKS.

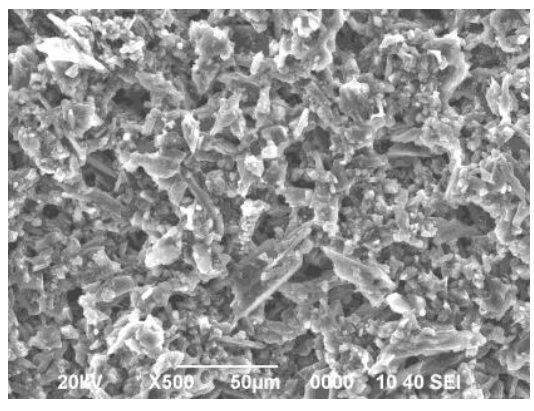

(a)

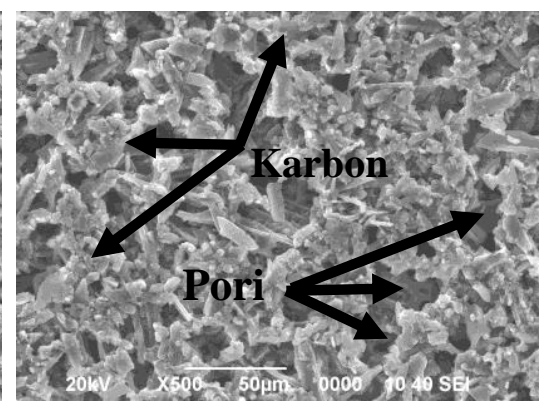

(b)

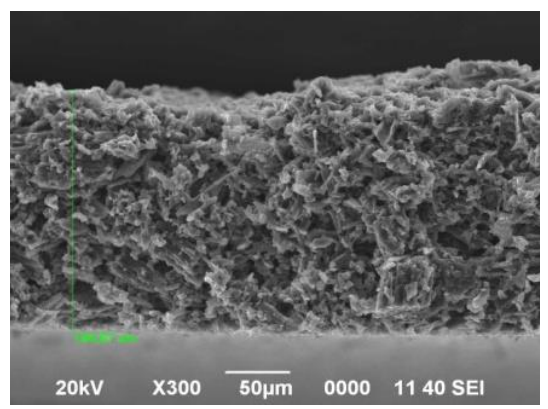

(c)

Gambar 6. Foto SEM kertas karbon dari arang TKKS tampak (a) permukaan atas, (b) permukaan bawah, dan (c) penampang lintang

\section{KESIMPULAN}

Proses karbonisasi serat tandan kosong kelapa sawit (TKKS) dalam suasana inert gas hingga suhu $1300^{\circ} \mathrm{C}$ dapat menghasilkan serbuk karbon yang cukup konduktif dengan nilai konduktivitas listrik sebesar $\pm(7,97-8,03)$ $\mathrm{S} / \mathrm{cm}$ (tidak ada dipembahasan). Pembuatan kertas karbon dengan memanfaatkan serbuk karbon dari serat TKKS ini berhasil dilakukan dengan teknologi casting yang sederhana dan menghasilkan kertas dengan dimensi sebesar $\pm(10 \times 10) \mathrm{cm}$ dan tebal $\pm(0,1-0,2) \mathrm{mm}$ Kertas karbon yang paling konduktif dihasilkan dari karbon TKKS $1300^{\circ} \mathrm{C}$ dengan nilai konduktivitas listrik kertas karbon $(2,34-2,40) \times 10^{-1} \mathrm{~S} / \mathrm{cm}$.

\section{UCAPAN TERIMA KASIH}

Penelitian ini merupakan bagian dari penelitian berjudul "Peningkatan Nilai Tandan Kosong Kelapa Sawit Menjadi Karbon Aktif Untuk Bahan Kertas Konduktif Sebagai Komponen Fuel Cell” dan didanai oleh kegiatan Insentif Peningkatan Kemampuan Peneliti dan Perekayasa (PKPP) Tahun Anggaran 2012, Kementerian Riset dan Teknologi. Penulis juga ingin mengucapkan terima kasih kepada semua pihak yang telah berkontribusi membantu pelaksanaan penelitian ini. 
12 | Fredina Destyorini, dkk., Pemanfaatan Tandan Kosong Kelapa Sawit....,

\section{DAFTAR PUSTAKA}

[1] Mo, Y. "7 Negara Tujuan Utama Ekspor Minyak Kelapa Sawit dari Indonesia”, http://www.isw.co.id/single-post/2017/02/27/Negara-Tujuan-Utama-Ekspor-Minyak-Kelapa-Sawit-dariIndonesia, akses tanggal 21 Desember 2017.

[2] Indonesian Palm Oil Magazine. http://www.infosawit.com/. Akses tanggal 1 November 2012.

[3] Manambangtua A P, Barri N L dan Palma B 2016 Warta Penelitian dan Pengembangan Tanaman Industri 2218

[4] Nurbahar I R, Hendaryati D D, Ariyanto Y Y, Zuraina W K, Pudjianto E, Udin A, Kurniawati N, Darmajati S N dan Magdalena E 2017 Statistik Perkebunan Indonesia, Kelapa Sawit 2015-2017 Sekretariat Direktorat Jenderal Perkebunan, Direktorat Jenderal Perkebunan, Kementerian Pertanian.

[5] Fuadi A M dan Pranoto H 2016 Chemica 31

[6] Mochidzuki K et al. 2003 Ind. Eng. Chem. Res. 425140

[7] Indayaningsih N, Zulfia A, Priadi D dan Kartini E 2010 Carbon Studies On The Oil Palm Fibers For Gas Diffusion Layer Material Proceeding 12th Asian Conference on Solid State Ionics and 15th Chinese Conference on Solid State Ionics, Fundamental researches and Technological Applications (Wuhan, China) p 1045

[8] Indayaningsih N, Zulfia A, Priadi D dan Hendrana S 2011 Jurnal Advanced Materials Research 277137

[9] Hussain R, Qadeer R, Ahmad M dan Saleem M 2000 Turk J. Chem. 24177

[10] Kercher A K dan Negle D C 2003 Carbon 4115

[11] Destyorini F, Suhandi A, Subhan A dan Indayaningsih N 2010 Jurnal Fisika Himpunan Fisika Indonesia 10122

[12] Cindrella L, Kannan A M, Lin J F, Saminathan K., Ho Y, Lin CW and Wertz J 2009 Journal of Power Sources 194146 